\section{JURNAL EKONOMI EFEKTIF}

ISSN : $2622-8882$, E-ISSN : 2622-9935

Jurnal Ekonomi Efektif, Vol. 3, No. 3, April 2021

@Prodi Manajemen Fakultas Ekonomi Universitas

Pamulang

\title{
PENGARUH STRESS KERJA TERHADAP KINERJA KARYAWAN PADA PT. PLN (PERSERO) AREA PONDOK AREN, TANGERANG SELATAN
}

\author{
Mitri Nelsi \\ Universitas Pamulang, Tangerang Selatan, Banten, Indonesia \\ dosen02493@unpam.ac.id
}

Manuskrip: Mar-2021 Ditinjau: Mar-2021; Diterima: Mar-2021; Online: Apr-2021; Diterbitkan: Apr-2021

\begin{abstract}
ABSTRAK
Penelitian ini bertujuan untuk mengetahui pengaruh stress kerja terhadap kinerja karyawan pada PT. PLN (Persero) Area Pondok Aren, Tangerang Selatan. Metode yang digunakan adalah explanatory research dengan sampel sebanyak 86 responden. Teknik analisis menggunakan analisis statistik dengan pengujian regresi, korelasi, determinasi dan uji hipotesis. Hasil penelitian ini variabel stress kerja diperoleh nilai rata-rata skor sebesar 3,486 dengan kriteria baik. Variabel kinerja karyawan diperoleh nilai rata-rata skor sebesar 3,076 dengan kriteria baik. Stress kerja berpengaruh positif dan signifikan terhadap kinerja karyawan dengan nilai persamaan regresi $Y=50,558-0,568 X$, dan nilai koefisien korelasi - 0,626 atau memiliki tingkat hubungan yang negatif kuat dengan nilai determinasi 39,2\%. Uji hipotesis diperoleh signifikansi $0,000<0,05$.
\end{abstract}

\section{Kata Kunci: Stress Kerja, Kinerja Karyawan.}

\section{ABSTRACT}

This study aims to determine the effect of job stress on employee performance at PT. PLN (Persero) Pondok Aren Area, South Tangerang. The method used is explanatory research with a sample of 86 respondents. The analysis technique uses statistical analysis with regression testing, correlation, determination and hypothesis testing. The results of this research variable work stress obtained an average score of 3.486 with good criteria. Employee performance variables obtained an average score of 3.076 with good criteria. Job stress has a positive and significant effect on employee performance with the regression equation $Y=$ $50.558-0.568 X$, and the correlation coefficient value - 0.626 or has a strong negative relationship level with a determination value of 39.2\%. Hypothesis testing obtained a significance of $0.000<0.0$.

Keywords: Job Stress, Employee Performance. 


\section{PENDAHULUAN}

\section{A. Latar Belakang Masalah}

Pada era globalisasi ini menyebabkan berkembang pesatnya teknologi dan informasi dunia. Persaingan semakin ketat sehingga mengharuskan perusahaan mampu menyusun rencana dalam jangka panjang untuk menghindari ketertinggalan dalam perkembangan dunia. Sumber daya manusia memiliki peranan penting bagi perusahaan, karena apabila sumber daya yang ada dalam perusahaan memiliki kompetensi yang tinggi maka perusahaan tersebut akan lebih mudah bersaing dan mencapai tujuan yang telah direncanakan.

Sumber daya manusia dikatakan memiliki andil yang besar dalam mencapai tujuan perusahaan karena apabila sumber daya manusia dalam suatu perusahaan memiliki kompetensi yang memadai maka akan lebih mudah dalam penggunaan teknologi yang ada. Faktor sumber daya manusia merupakan faktor pendorong utama karena di tangan manusialah segala inovasi tercipta dan dapat terwujud demi kelangsungan hidup perusahaan.

Agar perusahaan memiliki sumber daya yang mempunyai tingkat kompetensi yang tinggi, beberapa masalah dalam perusahaan harus dapat dicegah dan diatasi oleh perusahaan salah satunya masalah stress karyawan yang kemungkinan sangat dapat berdampak besar pada kinerja karyawan di dalam perusahaan. Stress di tempat kerja merupakan hal yang dapat terjadi hampir di setiap harinya dalam suatu perusahaan atau organisasi, Tingkat stress karyawan yang tinggi dapat memicu menghambat kinerja yang dihasilkan oleh karyawan.

Menurut Anwar Prabu (2013: 157) stress adalah perasaan tertekan yang dialami karyawan dalam menghadapi pekerjaan. Tingkat stress yang dialami pada setiap karyawan berbeda-beda, dan setiap karyawan memiliki cara masing- masing untuk menghadapinya. Stres dapat sangat membantu atau fungsional. Tetapi juga dapat berperan salah atau dapat merusak prestasi kerja. Menurut Handoko (2010: 201). Secara sederhana berati stres mempunyai potensi untuk mendorong atau mengganggu pelaksanaan kinerja, tergantung seberapa besar tingkat stres yang dialami karyawan.

Menurut Anwar Prabu mangkunegara (2011: 67) kinerja adalah hasil kerja secara kualitas dan kuantitas yang dicapai oleh seorang pegawai dalam melaksanakan tugasnya sesuai dengan tanggung jawab yang diberikan oleh perusahaan kepadanya. kinerja karyawan yang dicapai merupakan kualitas, kuantitas dan juga hasil dari apa yang di bebankan terhadap karyawan.

Stres kerja sangat mempengaruh terhadap kinerja yang dihasilkan oleh karyawan, apabila karyawan tidak dapat mengatasi stres yang dialaminya maka hal tersebut dapat menghambat kinerja karyawan. Apabila Kinerja yang dihasilkan menurun cepat atau lambat hal tersebut dapat berdampak buruk pula bagi perusahaan. Perusahaan kemungkinan besar akan mengalami kerugian sebagai dampak dari menurunnya kinerja yang dihasilkan karyawan.

Tabel 1

Data Beban Kerja Karyawan

\begin{tabular}{|c|l|c|c|c|c|}
\hline No & \multicolumn{1}{|c|}{ Bagian } & $\begin{array}{c}\text { Jumlah Beban } \\
\text { Kerja }\end{array}$ & $\begin{array}{c}\text { Jumlah } \\
\text { Pegawai }\end{array}$ & $\begin{array}{c}\text { Perhitungan jumlah } \\
\text { kebutuhan pegawai }\end{array}$ & $+/-$ \\
\hline 1 & $\begin{array}{l}\text { KSA (Keuangan, } \\
\text { Sekretariat dan } \\
\text { Administrasi) }\end{array}$ & 75 & 14 & 14 & 0 \\
\hline 2 & Distribusi & 130 & 24 & 26 & 2 \\
\hline 3 & $\begin{array}{l}\text { Pengadaan } \\
\text { Barang Dan Jasa }\end{array}$ & 37 & 2 & 4 & 2 \\
\hline
\end{tabular}




\begin{tabular}{|c|l|c|c|c|c|}
\hline 4 & Transaksi Energi & 125 & 22 & 23 & 1 \\
\hline 5 & Perencanaan & 85 & 7 & 9 & 2 \\
\hline 6 & Niaga & 110 & 14 & 15 & 1 \\
\hline 7 & Konstruksi & 103 & 14 & 14 & 0 \\
\hline 8 & Fungsional Ahli & 38 & 7 & 9 & 2 \\
\hline Total & & 703 & 104 & 114 & -10 \\
\hline
\end{tabular}

Sumber : PT. PLN (Persero) Area Pondok Aren, Tangerang Selatan

Banyak karyawan yang mengeluhkan beban kerja yang di berikan pimpinan berlebihan, menyebabkan karyawan kelelahan sehingga hal tersebut menimbulkan stress kerja pada karyawan. kekurangan karyawan dalam perusahaan juga menyebabkan beban yang diberikan kepada masing- masing karyawan menjadi berlebih. Karyawan juga merasa kekurangan waktu dalam mengerjakan tugas yang di bebankan oleh pimpinan, konflik antara karyawan satu dengan karyawan yang lainnya di sebabkan karena kelelahan akibat terlalu banyak beban kerja yang diberikan.

Tabel 2

Data Kinerja Karyawan

\begin{tabular}{|c|c|c|c|c|c|}
\hline No & Indikator kinerja & Satuan & Target & Realisasi & Keterangan \\
\hline 1 & Penambahan jumlah pelanggan & pelanggan & $8,946.00$ & $8,829.00$ & Hati-hati \\
\hline 2 & Penjualan Energi Total & MWh & $3,673,517$ & $3,412,617$ & Masalah \\
\hline 3 & Kecepatan Pelayanan & Hari & 5.00 & 3.08 & Baik \\
\hline 4 & Respon Time & Menit & 39.00 & 40,71 & Hati-hati \\
\hline 5 & Jumlah gangguan JTR/100Kms & $\%$ & 130.06 & 180.04 & Masalah \\
\hline 6 & $\begin{array}{l}\text { Keberhasilanfungsi GDF } \\
\text { Manual }\end{array}$ & $\%$ & 99.00 & 94.00 & Hati-hati \\
\hline 7 & Jumlah koreksi rekening & $\%$ & 0.0089 & 0.0018 & Baik \\
\hline 8 & Gangguan SR/APP & $\begin{array}{l}\text { Kali/1000 } \\
\text { Pelanggan }\end{array}$ & 36.68 & 42.71 & Masalah \\
\hline 9 & Penanganan keluhan pelanggan & Hari kerja & 2.0 & 2.03 & Hati-hati \\
\hline 10 & Komplain Pelanggan & $\%$ & 5.00 & 4.47 & Baik \\
\hline 11 & $\begin{array}{l}\text { Jumlah penjualan energi } \\
\text { pelanggan industri }\end{array}$ & MWh & $40,020.60$ & 33,070 & Masalah \\
\hline 12 & $\begin{array}{l}\text { Keberhasilan fungsi GFD } \\
\text { Manual }\end{array}$ & $\%$ & 99.00 & 94.60 & Hati-hati \\
\hline 13 & Hasil Produktifitas Pegawai & $\begin{array}{l}\text { KWh jual / } \\
\text { pegawai }\end{array}$ & $35,322.28$ & $34,280.08$ & Hati-hati \\
\hline 14 & Harga jual rata-rata & $\mathrm{Rp} / \mathrm{KWh}$ & $1,331.79$ & $1,196.76$ & Masalah \\
\hline 15 & Umur Piutang (PAL+75+PRR) & Hari & 30,49 & 28,83 & Masalah \\
\hline 16 & Efektifitas biaya pemeliharaan & $\%$ & 2.90 & 3.87 & Masalah \\
\hline 17 & $\begin{array}{l}\text { Penyerapan biaya disburse } \\
\text { investasi PLN }\end{array}$ & $\%$ & 90.00 & 96.40 & Baik \\
\hline 18 & Implementasi $\mathrm{K} 2$ & Skor & 100.00 & 75.00 & Masalah \\
\hline 19 & ERM & Level & 3.50 & 3.45 & Hati-hati \\
\hline 20 & $\begin{array}{l}\text { Kepatuhan keselamatan, } \\
\text { kelengkapan data laporan, surat } \\
\text { teguran }\end{array}$ & $\%$ & 100.00 & 100.00 & Baik \\
\hline
\end{tabular}

Sumber : PT. PLN (Persero) Area Pondok Aren, Tangerang Selatan

Dari data tersebut di atas dapat di simpulkan bahwa: kinerja karyawan pada bulan Januari sampai dengan Desember 2016 banyak mengalami masalah hal tersebut di sebabkan karena stres kerja yang di alami kayawan sehingga menyebabkan banyaknya permasalahan yang timbul dalam pekerjaan dan juga penurunan kinerja.

Berkaitan dengan masalah tersebut, penulis tertarik untuk meninjau dan melakukan penelitian yang bekaitan dengan stress kerja tersebut maka penulis mengambil judul "Pengaruh Stress Kerja Terhadap Kinerja Pada PT. PLN (Persero) Area Pondok Aren, Tangerang Selatan" 


\section{B. Rumusan Masalah}

1. Bagaimana stress kerja pada PT. PLN (Persero) Area Pondok Aren, Tangerang Selatan?.

2. Bagaimana kinerja karyawan pada PT. PLN (Persero) Area Pondok Aren, Tangerang Selatan?.

3. Adakah pengaruh antara stress kerja terhadap kinerja karyawan pada PT. PLN (Persero) Area Pondok Aren, Tangerang Selatan ?

\section{Tujuan Penelitian}

1. Untuk mengetahui kondisi stress kerja pada PT. PLN (Persero) Area Pondok Aren, Tangerang Selatan.

2. Untuk mengetahui kondisi kinerja karyawan pada PT. PLN (Persero) Area Pondok Aren, Tangerang Selatan.

3. Untuk mengetahui pengaruh antara stress kerja terhadap kinerja karyawan pada PT. PLN (Persero) Area Pondok Aren, Tangerang Selatan.

\section{METODE PENELITIAN}

\section{Populasi}

Populasi dalam penelitian ini berjumlah 86 responden PT. PLN (Persero) Area Pondok Aren, Tangerang Selatan

\section{Sampel}

Teknik pengambilan sampling dalam penelitian ini adalah sampel jenuh, dimana semua anggota populasi dijadikan sebagai sampel. Dengan demikian sampel dalam penelitian ini sampel yang digunakan berjumlah 86 responden.

\section{Jenis Penelitian}

Jenis penelitian yang dipakai adalah asosiatif, dimana tujuannya adalah untuk mengetahui atau mencari keterhubungan antara variabel independen terhadap variabel dependennya

\section{Metode Analisis Data}

Dalam menganalisis data digunakan uji validitas, uji reliabilitas, analisis regresi linier sederhana, analisis koefisien korelasi, analisis koefisien determinasi dan pengujian hipotesis.

\section{HASIL PENELITIAN DAN PEMBAHASAN}

\section{Analisis Deskriptif}

Pada pengujian ini digunakan untuk mengetahui skor minimum dan maksimum skor tertinggi, ratting score dan standar deviasi dari masing-masing variabel. Adapun hasilnya sebagai berikut:

Tabel 3. Hasil Analisis Descriptive Statistics

\section{Descriptive Statistics}

\begin{tabular}{lr|r|r|r|r} 
& N & \multicolumn{1}{|c|}{ Minimum } & Maximum & \multicolumn{1}{c}{ Mean } & \multicolumn{1}{c}{ Std. Deviation } \\
\hline Stress kerja (X) & 86 & 16 & 49 & 34.86 & 7.777 \\
\hline Kinerja Karyawan (Y) & 86 & 17 & 46 & 30.76 & 7.058 \\
\hline Valid N (listwise) & 86 & & & & \\
\hline
\end{tabular}

Stress kerja diperoleh varians minimum sebesar 16 dan varians maximum 49 dengan ratting score sebesar 3,486 dengan standar deviasi 7,777. Skor ini termasuk pada rentang sakala 3,40 - 4,19 dengan kriteria baik atau setuju.

Kinerja karyawan diperoleh varians minimum sebesar 17 dan varians maximum 46 
dengan ratting score sebesar 3,076 dengan standar deviasi 7,058. Skor ini termasuk pada rentang sakala 2,60 - 3,39 dengan kriteria kurang baik atau kurang setuju

\section{Analisis Verifikatif.}

Pada analisis ini dimaksudkan untuk mengetahui pengaruh variabel independen terhadap variabel dependen. Adapun hasil pengujian sebagai berikut:

\section{a. Analisis Regresi Linier Sederhana}

Uji regresi ini dimaksudkan untuk mengetahui perubahan variabel dependen jika variabel independen mengalami perubahan. Adapun hasil pengujiannya sebagai berikut:

Tabel 4. Hasil Pengujian Regresi Linier Sederhana Coefficients $^{\mathrm{a}}$

Unstandardized

\begin{tabular}{|c|c|c|c|c|c|}
\hline \multirow[b]{2}{*}{ Model } & \multicolumn{2}{|c|}{$\begin{array}{c}\text { Unstandardized } \\
\text { Coefficients }\end{array}$} & \multirow{2}{*}{$\begin{array}{c}\text { Standardized } \\
\text { Coefficients } \\
\text { Beta }\end{array}$} & \multirow[b]{2}{*}{$\mathrm{t}$} & \multirow[b]{2}{*}{ Sig. } \\
\hline & $\mathrm{B}$ & Std. Error & & & \\
\hline 1 (Constant) & 50.558 & 2.758 & & 18.334 & .000 \\
\hline Stress kerja (X) & -.568 & .077 & -.626 & -7.355 & .000 \\
\hline
\end{tabular}

Berdasarkan hasil pengujian pada tabel di atas, diperoleh persamaan regresi $\mathrm{Y}$ $=50,558-0,568 X$. Dari persamaan tersebut dijelaskan sebagai berikut:

1) Konstanta sebesar 50,558 diartikan jika stress kerja tidak ada, maka telah terdapat nilai kinerja karyawan sebesar 50,558 point.

2) Koefisien regresi stress kerja sebesar - 0,568, angka ini negatif artinya setiap ada peningkatan stress kerja sebesar 0,568 point maka kinerja karyawan juga akan mengalami penurunan sebesar - 0,568 point.

\section{b. Analisis Koefisien Korelasi}

Analisis koefisien korelasi dimaksudkan untuk mengetahui tingkat kekuatan hubungan dari variabel independen terhadap variabel dependen. Adapun hasil pengujian sebagai berikut:

Tabel 5. Hasil Pengujian Koefisien Korelasi Stress kerja Terhadap Kinerja Karyawan.

\section{Correlations $^{\text {b }}$}

\begin{tabular}{llr|r} 
& & & \multicolumn{2}{c}{$\begin{array}{r}\text { Kinerja Karyawan } \\
\text { (Y) }\end{array}$} \\
\hline Stress kerja $(\mathrm{X})$ & Stress kerja (X1) & 1 & $-.626^{* *}$ \\
\cline { 2 - 4 } & Pearson Correlation & & .000 \\
\hline Kinerja Karyawan (Y) $(\mathrm{Y})$ & Pearson Correlation & $-.626^{* *}$ & 1 \\
\cline { 2 - 4 } & Sig. (2-tailed) & .000 & \\
\hline
\end{tabular}

Berdasarkan hasil pengujian diperoleh nilai korelasi sebesar - 0,626 artinya stress kerja memiliki hubungan yang negatif kuat terhadap kinerja karyawan.

\section{c. Analisis Koefisien Determinasi}

Analisis koefisien determinasi dimaksudkan untuk mengetahui besarnya persentase pengaruh dari variabel independen terhadap variabel dependen. Adapun hasil pengujian sebagai berikut:

Tabel 6. Hasil Pengujian Koefisien Determinasi Stress kerja Terhadap Kinerja

Karyawan.

Model Summary

\begin{tabular}{lrr|r|r|r} 
Model & R & R Square & Adjusted R Square & Std. Error of the Estimate \\
\hline 1 & $.626^{\mathrm{a}}$ & .392 & .385 & 5.537 \\
\hline
\end{tabular}

Berdasarkan hasil pengujian diperoleh nilai determinasi sebesar 0,392 artinya 
stress kerja memiliki kontribusi pengaruh sebesar 39,2\% terhadap kinerja karyawan, sedangkan sisanya sebesar $60,8 \%$ dipengaruhi oleh faktor lain yang tidak dilakukan penelitian.

\section{d. Uji Hipotesis}

Pengujian hipotesis dengan uji t digunakan untuk mengetahui hipotesis mana yang diterima. Rumusan hipotesis: Terdapat pengaruh yang negatif signifikan antara stress kerja terhadap kinerja karyawan.

Tabel 7. Hasil Uji Hipotesis Stress kerja Terhadap Kinerja Karyawan.

\begin{tabular}{|c|c|c|c|c|c|c|}
\hline \multirow{3}{*}{\multicolumn{2}{|c|}{ Model }} & \multicolumn{5}{|c|}{ Coefficients $^{\mathrm{a}}$} \\
\hline & & \multicolumn{2}{|c|}{$\begin{array}{l}\text { Unstandardized } \\
\text { Coefficients }\end{array}$} & \multirow{2}{*}{$\begin{array}{c}\text { Standardized } \\
\text { Coefficients } \\
\text { Beta }\end{array}$} & \multirow[t]{2}{*}{$\mathrm{t}$} & \multirow{2}{*}{ Sig. } \\
\hline & & $\mathrm{B}$ & Std. Error & & & \\
\hline \multirow[t]{2}{*}{1} & (Constant) & 50.558 & 2.758 & & 18.334 & .000 \\
\hline & Stress kerja (X) & -.568 & .077 & -.626 & -7.355 & .000 \\
\hline
\end{tabular}

Berdasarkan hasil pengujian pada tabel di atas, diperoleh nilai t hitung $<\mathrm{t}$ tabel atau $(-7,355<1,989)$, dengan demikian hipotesis yang diajukan bahwa terdapat pengaruh yang negatif signifikan atara stress kerja terhadap kinerja karyawan diterima.

\section{PEMBAHASAN HASIL PENELITIAN}

\section{Kondisi Jawaban Responden Variabel Stress kerja}

Berdasarkan jawaban responden, variabel stress kerja diperoleh ratting score sebesar 3,486 berada di rentang skala 3,40 - 4,19 dengan kriteria baik atau setuju.

\section{Kondisi Jawaban Responden Variabel Kinerja Karyawan}

Berdasarkan jawaban responden, variabel kinerja karyawan diperoleh ratting score sebesar 3,076 berada di rentang skala 2,60 - 3,39 dengan kriteria kurang baik atau kurang setuju.

\section{Pengaruh Stress kerja Terhadap Kinerja Karyawan}

Stress kerja berpengaruh signifikan terhadap kinerja karyawan dengan persamaan regresi $\mathrm{Y}=50,558-0,568 \mathrm{X}$, nilai korelasi sebesar - 0,626 atau memiliki hubungan yang negatif kuat dengan kontribusi pengaruh sebesar 39,2\%. Pengujian hipotesis diperoleh nilai $t$ hitung $<\mathrm{t}$ tabel atau $(-7,355<1,989)$. Dengan demikian hipotesis yang diajukan bahwa terdapat berpengaruh negatif signifikan antara stress kerja terhadap kinerja karyawan diterima.

\section{V.PENUTUP}

\section{Kesimpulan}

a. Variabel stress kerja diperoleh ratting score sebesar 3,486 berada di rentang skala 3,40 - 4,19 dengan kriteria baik atau setuju.

b. Variabel kinerja karyawan diperoleh ratting score sebesar 3,076 berada di rentang skala 2,60 - 3,39 dengan kriteria kurang baik atau kurang setuju.

c. Stress kerja berpengaruh signifikan terhadap kinerja karyawan dengan persamaan regresi $\mathrm{Y}=50,558+-0,568 \mathrm{X}$, nilai korelasi sebesar $-0,626$ atau kuat dan kontribusi pengaruh sebesar $39,2 \%$ sedangkan sisanya sebesar $60,8 \%$ dipengaruhi faktor lain. Uji hipotesis diperoleh nilai t hitung $<\mathrm{t}$ tabel atau $(-7,355<1,989)$. 


\section{Saran}

a. Sebaiknya perusahaan memberikan waktu yang lebih memadai untuk karyawan menyelesaikan pekerjaan. Selain itu pimpinan juga perlu bersikap adil terhadap setiap karyawan.

b. Karyawan perlu meningkatkan kecermatan serta ketelitian dalam mengerjakan tugasnya. Dan sebaiknya karyawan dapat mengerjakan dengan baik tugas yang di berikan oleh pimpinan.

c. Perusahaan yang maju dan berkembang dinilai dari seberapa perdulinya perusahaan dalam memberikan waktu kerja yang memadai serta dapat meningkatkan kinerja karyawannya.

\section{DAFTAR PUSTAKA}

Affandi, A., Sarwani, A. S., Erlangga, H., Siagian, A. O., Purwanto, A., Effendy, A. A., ... \& Wahyitno, C. D. M. (2020). Optimization of MSMEs Empowerment in Facing Competition in the Global Market during the COVID-19 Pandemic Time. Systematic Reviews in Pharmacy, 11(11), 1506-1515.

Arikunto, Suharsimi (2014). "Prosedur Penelitian Suatu Pendekatan Praktek". Jakarta: Rineka Cipta.

Barsah, A. (2019). Pengaruh Motivasi Dan Disiplin Terhadap Kinerja Pegawai Pada Dinas Kependudukan Dan Pencatatan Sipil Kota Tangerang. JENIUS (Jurnal Ilmiah Manajemen Sumber Daya Manusia), 3(1), 1-15.

Danang, Sunyoto. 2010. "Manajemen Sumber Daya Manusia”, Jakarta : PT. Buku Seru

Eka, P. D. (2020). Analisis Pengaruh Keselamatan Kerja Dan Pelatihan Terhadap Kinerja Karyawan Pada PT Berca Schindler Lifts Project Alfa Tower Tangerang. JENIUS (Jurnal Ilmiah Manajemen Sumber Daya Manusia), 3(2), 198-207.

Hani Handoko T. 2009. "Manajemen Sumber Daya Manusia" Edisi ke 3, Yogyakarta Hariandja, Marihot Tua Evendi. 2007. "Manajemen Sumber Daya Manusia ; Pengadaan, Pengembangan, Pengkompensasian, dan Peningkatan Produktifitas Pegawai". Jakarta: Grasindo

Hasibuan, Malayu S.P. 2010.”Manajmen Sumber Daya Manusia" Jakarta : PT. Bumi Aksara.

Hermita, 2011. "Pengaruh Stres Kerja Terhadap Kinerja Karyawan Pada PT Semen Tonasa (Persero) Pangkep" Jurnal Universitas Hasanudin Makasar

Hulaif Gaffar, 2012. "Pengaruh Stres Kerja Terhadap Kinerja Karyawan pada PT Bank Mandiri (Persero) Tbk". Jurnal Universitas Hasanudin Makasar

Jasmani, J., \& Paeno, P. (2019). The Effect of Leadership and Competence on Lecturer Performance and Its Implications on Student Learning Motivation at Pamulang University. International Journal of Advances in Social and Economics, 1(4).

Jasmani, J., \& Sunarsi, D. (2020). The Influence of Product Mix, Promotion Mix and Brand Image on Consumer Purchasing Decisions of Sari Roti Products in South Tangerang. PINISI Discretion Review, 1(1), 165-174.

Kaso, N., Mariani, M., Ilham, D., Firman, F., Aswar, N., \& Iksan, M. (2021). The Principal's Leadership: How to Improve the Quality of Teaching and Learning Process in State Junior High School of Luwu. Jurnal Ad'ministrare, 8(1), 49-58. https://doi.org/10.26858/ja.v8i1.19126

Mangkunegara, Anwar Prabu A.A. 2013. "Manajemen Sumber Manusia", Cetakan Kesebelas. Bandung: PT. Remaja Rosdakarya.

Noor'aini Aslihah, 2015. "Pengaruh Stres Kerja Terhadap Kinerja Karyawan di Koperasi Syari’ah Binama Semarang”.Jurnal Universitas Islam Negri Walisongo Semarang 
Oki HSP Sihobing, 2012. "Pengaruh Stres kerja Terhadap Kinerja karyawan pada PT Indah Mandiri Sari Medan". Jurnal Universitas Sumatera Utara Medan

Ria Puspita Sari, 2015. "Pengaruh Stres Kerja dan Konflik Kerja Terhadap Kierja Karyawan Jambuluwuk Malioboro Boutique Hotel Yogyakarta”.Jurnal Universitas Negri Yogyakarta.

Rivai, Veithzal. 2014."Manajemen Sumber Daya Manusia Untuk Perusahaan, dari Teori ke Praktik". Jakarta : PT. Raja Grafindo Persada.

Sondang P Siagian, 2016. "Manajemen Sumber Daya Manusia". Bumi Aksara.

Sugiyono, 2016. "Metode Penelitian Kombinasi". Cetakan Ketujuh, Alfabeta, Bandung.

T. Hani Handoko, 2014. "Manajemen Personalia dan Sumber Daya Manusia". BPFEUGM, Yogyakarta. 